DOI 10.31558/2519-2949.2021.3.4

УДК $321 / 324 / 328$

ORCID ID: https://orcid.org/0000-0002-1055-1629

Мішин С. І., Національний університет «Одеська юридична академія»

\title{
ДЕМОКРАТИЧНІ ЗМІНИ: КРИТЕРІЇ ТА ФАКТОРИ
}

Стаття направлена на дослідження демократичних змін в аспекті характеристики критерїв та факторів даних трансформачій. Сучасний політичний процес може мати різні траєкторії та коливання. Саме вони визначають напрямки політичних трансформацій. Це можуть бути широкий спектр політичних режимів: від демократій до нових форм автократії та диктатур. I важливим тут є визначення того, які є об 'єктивні умови, які сприяють або перешкоджають формуванню нових демократичних інституиій. Тому, дана стаття звертає увагу на виявлення ключових факторів, що впливають на траєкторії та результати режимних змін. Безпосередньо, увагу направлено на аналіз факторів та прочесів, які мають значення для пояснення характеру та результатів режимних трансформацій.

Визначено, що актуальним завданням зараз є використання можливостей, які виникають в перехідних прочесах в мінливих суспільствах. Це необхідно для одночасного поглиблення задач, що стоять перед демократією та розвитком. Необхідним є забезпечення того, щоб начіональні плани розвитку та економічні реформи набули всеохоплюючого та колективного характеру, щоб інститути держави ставали все більш підзвітними і щоб структура виборчих і конституційних процесів забезпечувала максимальну участь громадян, особливо меншин, жінок і вразливих груп населення. Підзвітність та прозорість, засновані на принципі стримувань та противаг є головними складовими, які в найближчі роки залишаються однією з найважливіших задач для краӥн, де формується демократія і це має вирішальне значення для перспектив їх розвитку.

Обтрунтовано, що слід переосмислити традиційний підхід до зміинення демократії, а також загальноприйняті порядки надання допомоги в иілях розвитку. Також слід більш глибоко опрацювати конщепцію демократичного розвитку. Особливо звернути увагу на визначення мети такого розвитку: усування відособленості в справі зміцнення демократії і практиці здійснення партнерства заради розвитку, особливо в плані узгодженості їх реалізачії, визначення рівня впливу прав та участі громадян на ймовірність стійкого прогресу розвитку суспільства та держави.

Ключові слова: демократія, трансформачї, зміни, демократичний режим, політичні трансформаиї.

Постановка проблеми у загальному вигляді. В сучасному політичному процесі існують різні траєкторії політичних трансформацій, які характеризуються широким спектром політичних режимів: від консолідованих ліберальних демократій до різних «гібридів», нових форм автократії різних типів та диктатур. І тут виникає питання: чи існують якісь специфічні об'єктивні умови, які сприяють або перешкоджають формуванню нових демократичних інститутів та практик, хто або що визначає межі демократичного розвитку в конкретному історичному контексті. Тому слід звернути увагу на виявлення ключових факторів, що впливають на траєкторії $\mathrm{i}$ результати режимних змін. Безпосередньо, увагу буде зосереджено на тому, які з цих факторів і в яких ситуаціях найбільш значущі для пояснення характеру і результатів режимних трансформацій.

Аналіз останніх досліджень і публікацій. Дослідження у напрямку розвитку демократії ведуться завжди. Ми зараз мається багатий матеріал різних часів з даної проблематики. Але аспектів, яких стосується демократичний рух суспільства їх дуже багато. Безумовно, ми спираємося на дослідження класичні дослідження зарубіжних авторів: С.Гантінгтона, Ш.Ейзенштадта, Р.Інглегарта, Д.Норта, А.Пшеворського, Дж.Сарторі тощо. Українська політична наука також активно приймає участь в дослідженні демократичних змін. Слід відзначити розробки таких авторів як М. Головатий, В.Горбатенко, Г.Зеленько, А. Колодій, Ю. Шайгородський та інш. Багато цікавих робіт здійснено одеською школою політології, зокрема такими науковцями як Л.Кормич, С.Наумкіна, К.Вітман, М.Польовий, А.Пехник, А.Кройтор, Ю.Завгородня та інш. Голова увага в даній статті 
направлена на питання щодо перехідних процесів між політичними режимами, питання транзитів та коливань між ними. Особливо важливими $є$ проблеми визначення траєкторії коливань та факторів, які впливають на ці процеси. I це вимагає додаткових постійних досліджень.

Метою статті є: визначення розуміння демократичних змін в аспекті характеристики критеріїв та факторів даних трансформацій.

Виклад основного матеріалу. В політичній науці існує дві головні парадигми, які пояснюють рухи демократії: як вона виникає, формується та підтримується. Перша виникла в середині XX сторіччя та заснована на положенні, що виникнення інститутів політичної демократії $€$ результатом певних об'єктивних процесів та передумов. Тобто, демократія виникає як результат соціальних або економічних перетворень як оформлення результатів інших соціальних і економічних процесів. Такі структурні процеси та передумови мають різну природу і відносяться до історичних, соціальних та економічних факторів, особливостей створення нації та держави, типу політичної культури тощо. Важливим є те, що ці передумови мають історичну природу, вони об'єктивні і не залежать від конкретних рішень і дій політичних акторів. Відповідно, відсутність цих умов і передумов встановлює межі демократичного розвитку.

Наступна парадигма виникла пізніше і вона намагається розробити теоретичну модель пояснення режимних змін процесів демократизації. Особливо увага направлена на конкретні політичні рішення та дії політичних акторів, які мають функції розробки політичних стратегій та тактик. Парадигма передбачає, що формування демократичних інститутів та процедур не залежить від настання об’єктивних, структурних умов. В даному випадку мова йде про суб'єктивний фактор рішень та дій політичних акторів. Частіше маються на увазі елітні групи.

Перша передумова, це - формування ефективної державності, державної єдності та національної ідентичності. На мою думку, одна з головних умов демократії. Дійсно, коли відсутні ефективні державні інститути, це приводить до хаосу. Але, важливе питання в розумінні того, які критерії ефективності суспільство визначає. Це стосується й критеріїв якості державних інститутів.

Рівень економічного розвитку також виступає як умова демократії. Початкова теза полягає в тому, що відносно високий рівень економічного розвитку є умовою для демократії, оскільки породжує нову соціальну структуру. Мова йде про формування середнього класу, який вимагає представництва своїх інтересів за допомогою демократичних інститутів. Але, $є$ зауваження, яке слід вказати і на це є відповідні аргументи: демократизація може починатися при різних (інколи досить низьких) рівнях економічного розвитку, однак високий ВВП на душу населення $є$ гарантією проти занепаду існуючого демократичного режиму і його заміни авторитаризмом.

Наступна передумова демократичних змін - це політична культура громадянського типу. Це означає, що переходи до демократії можуть починатися в умовах, коли загальні громадські цінності є домінуючими та поширеними.

Перелік структурних факторів, які потенційно виступають як сприятливі чи несприятливі умови демократії, можна продовжити, наприклад, додати кліматичні умови чи загальнонаціональний рівень.

Відповідно до іншого підходу, наголос робиться на суб'єктивних факторах, що впливають на характер та спрямованість режимних трансформацій. Саме вони пояснюють траєкторії та результати транзиту. Першим фактором можна назвати характер та особливості виходу з авторитаризму (або посттоталітаризму) на демократичної трансформації. Наступний, - роль та вплив інституційного дизайну, що обирається для нової демократії (форма правління, характер партійної та виборчої систем та ін.). Далі можна виділити взаємовідносини з позицією та процес формування системи взаємодій між ключовими політичними акторами на всіх стадіях режимної трансформації. Тут мова також йде про зміну або збереження старих еліт в будь-яких перетворених формах.

Також, до таких факторів слід віднести ротацію влади як один із ключових критеріїв демократичного правління; рівні реальної (неформальній) політичної конкуренції; ставлення влади до політичного плюралізму; якість проведених виборів; використання владою чи опозицією насильства для досягнення політичних цілей та результатів; наявність ефективних інституційних обмежувачів (в тому числі реального поділу влади), що перешкоджають зловживанням виконавчої влади та ін.

Слід зазначити, що вплив об'єктивних факторів здійснюється через суб'єктивні дії реальних політичних акторів, в той час як особливості прийнятих акторами рішень і обраних ними стратегій та тактик, в свою чергу, мають свої коріння в специфіці історичних, культурно-цивілізаційних, соціально-економічних умовах. Тобто, структурні чинники мають особливе значення в розумінні 
процесу консолідації демократії в цьому процесі. Оскільки ці структурні умови не можуть бути змінені швидко, слід звертати більше уваги на ті умови, які можна змінити за допомогою політичної інженерії та політичного лідерства.

В цілому, ці підходи використовуються в науці в якості двох альтернативних пояснювальних моделей щодо аналізу режимних трансформацій, зокрема, до аналізу демократичних змін. Але, на мою думку, для вирішення актуальних питань демократичних перетворень слід виходити за межі даних парадигм.

Якщо говорити про «демократичний розвиток» то ту слід звернути увагу на співвідношення цих понять. Так, М.Томмазолі говорить, що «демократія та розвиток взаємно зміцнюють один одного. В процесі їх взаємодії та взаємного зміцнення просування уперед в одній області може привести до прогресу в іншій» [5, с. 6]. Також у цьому програмному документі використовується термін «сумлінне управління» і вказується, що раніше його використовували «як замінник ширшої концепції вкладу демократії в розвиток і його ролі в ньому». Але зараз ситуація змінилася і «саме демократія, а не лише сумлінне управління (гарне управління) відіграє важливу роль в розвитку, охоплюючи не тільки ключові інститути та процеси, а й концепції права громадян на вираження своєї думки, участі, всеосяжність та виховання демократичної культури» [5, с. 7].

В даному програмному документі представлені ключові відмінні ознаки демократії, такі як участь, всеосяжність, реагування на вимоги громадян і підзвітність. Вони вносять прямий та непрямий внесок у розвиток, коли вони поєднуються з можливостями держави щодо забезпечення охорони та безпеки, верховенства права та доступу до правосуддя, професійного державного управління та надання основних послуг в таких областях, як освіта та охорона здоров'я. одночасно, у програмному документі відзначається, що й злидні, голод та хвороби можуть обмежувати здатність людей ефективно реалізовувати свої політичні і громадянські права. Таким чином, «розвиток також має значення для демократії. Відсутність розвитку, що виражається у формі економічної стагнації, хронічного нерівності і / або крайньої убогості, може привести до підриву віри людей в формально демократичні системи управління навіть в тих країнах або регіонах, де ці системи вважалися міцно усталеними». Акцент на тому, що «демократичні порядки не завжди забезпечують досягнення результатів розвитку в тій мірі і такими темпами, яких очікують громадяни. Крім того, формальних і істотно важливих демократичних процесів, таких як організація та проведення регулярних змагальних виборів - яким міжнародні донори, які надають допомога в цілях зміцнення демократії, часто надають вельми важливе значення - самих по собі недостатньо, щоб поліпшити життя бідних верств населення» $[5$, с. 8$]$.

Для вимірювання рівня демократії, демократичних змін існують різні індекси та рейтинги i науковці використовують їх для визначення умов демократичних трансформацій. Так, наприклад, Д.Альтман, професор політології Католицького університету в Сантьяго-де-Чилі в своїй роботі «Громадянські права і сучасна пряма демократія» (2019) регулярно відстежує спроби створити якийсь ефективний і визнаний експертною спільнотою «демократомір» [1]. Той же Д. Альтман $є$ одним з авторів та експертів дослідницького проекту «Різновиди демократії» (V-Dem) [2]. Це великий проект зі збору емпіричних даних, які потім застосовуються з метою концептуального осмислення самого явища демократії у всьому його різноманітті. Проект V-Dem пропонує зовсім інший методологічний та концептуальний підхід. Зокрема, експерти застосовують більш ніж 350 показників демократичного розвитку.

Такі дослідження є дуже важливими. Наприклад, країни кожного року витрачають великі ресурси на просування демократії - як в своїх країнах, так і зовні. I тут виникає питання щодо дієвості цих інвестицій, які багато в чому залежать від того, наскільки адекватні сучасні оцінки становища тої або іншої країни та їх перспектив на майбутнє. Тому, різноманітні індекси та рейтинги, дослідження в цій області є дуже важливими. Наприклад, Швейцарія здійснює підтримку демократії в усьому світі і це $€$ визначено конституційною нормою. I саме тому, Швейцарія надає консультаційну підтримку Україні в частині розробки сучасного законодавства, що регулює порядок застосування норм та інструментів сучасної прямої демократії.

I щодо Швейцарії, країни зі сталою демократією, то тут слід звернутися до думки спеціаліста 3 питань прямої демократії Б.Кауфманна, який представив своє бачення, щодо складових, без яких не може обійтися жодне суспільство, якщо тільки воно хоче називатися демократичною [4]. До цих складових автор відносить наступні:

- Технології. У Швейцарії довгі роки йшли дебати і ставилися досліди на предмет введення електронного голосування за допомогою мережі Інтернет у віддаленому режимі. Така система була б 
великою підмогою для численної швейцарської діаспори за кордоном: громадяни Швейцарії могли б більш активно брати участь у політичному житті у себе на історичній батьківщині. На жаль, те, що змогла зробити Естонія, не вдалося Швейцарії, і поки цей формат голосування залишиться для швейцарців, які проживають за кордоном.

- Біг з перешкодами. Це бар'єри, мета яких полягає не в придушенні будь-якого реального політичного життя, але в тому, щоб у політиків були мотивації та стимули йти в народ, говорити з людьми, збирати підписи та переконувати потенційних виборців.

- Інфраструктура. Обраний парламент повинен мати відповідну інфраструктуру. Демократія не обмежується голосуванням раз на чотири роки, вона спирається на безпосередню участь громадян в управлінні та формуванні політичного порядку денного країни і потребує освічених, критично та раціонально мислячих громадян. А таким громадянам потрібні місця, де вони могли зустрічатися з владою. У Сеулі є, наприклад, «Будинок громадян».

- Навчання. Ступінь зрілості і рівень якості демократії можна виміряти за допомогою такого показника, як іiі здатність до постійної реформи. Треба йти вперед, приймати рішення, помилятися, аналізувати помилки, усувати їх і йти далі. I тільки так можна вибудувати сталу, спрямовану в майбутнє демократію. Постійно удосконалюючи та самонавчальна демократія - це завжди пряма демократія громадян.

- Керівні якості. Людина, яка обрана до влади починає захищати свої владні повноваження від будь-якого впливу та втручання. Для справжньої демократії така логіка - це «справжня отрута». Необхідно робити ставку на розподіл влади та демонструвати свої справжні керівні якості. Тобто вести за собою та керувати.

- Ті програв вибори повинні почувати себе також щасливими. Демократія будується на безумовному визнанні результатів народного волевиявлення усіма - i переможцями, i переможеними. Тому необхідно зробити так, щоб ті, хто вибори програв, не відчували себе знедоленими. У Швейцарії відповідь на це питання було свого часу знайдено на шляху до істинного федералізму.

- Адміністративний апарат. Між виборцями та обраними завжди є адміністративнобюрократичний апарат з його інерцією та схильністю зберігати і відстоювати сформовані структури, інструменти та підходи, які не завжди відзначені близькістю до народу і прагненням вислуховувати своїх громадян і враховувати їх думку . Саме тому чиновники повинні бути безпосередньо включені в структури безпосереднього народоправства. Тобто, адміністративно-бюрократичний апарат повинен бути вбудований в систему безпосереднього народоправства.

- Правова держава. «Ми всі знаємо, що коли суди знаходяться під керівництвом державної влади, а судові рішення - формою владного свавілля, то тоді громадянам і виборцям стає майже неможливо вільно висловлювати власну думку - а це означає, що в них відбирають можливість впливати на політику. Наприклад, в Росії ті, хто наважується критикувати режим В.Путіна, не тільки виключаються з виборчих процедур, а й просто виявляються в тюрмах. Саме тому, дійсно незалежна юстиція була і залишається інгредієнтом, без якого неможлива справжня демократія» [4].

- Право голосу. Будь-яке суспільство і будь-яка спільнота громадян існує тільки в умовах дії принципу інклюзивності, залучення всіх у суспільно важливі справи. У Швейцарії $25 \%$ осіб від загальної кількості, тих хто проживає в країні - не мають права голосу. Цю проблему багато міст і кантони прагнуть вирішити по різному, але мотивація у всіх одна: людина повинна мати право голосу там і тоді, де і коли мова йде про проблеми, що стосуються іiі безпосередньо. Тобто - реальні виборчі права - це важливо.

- Діалог. Ще Перікл визначав чим демократія відрізняється від не демократії: діалогом напередодні прийняття важливого рішення. 3 того часу нічого не змінилося: успіх демократичного рішення і його якість залежать від якості дискусії перед рішення. Наприклад, в Швейцарії в двох швейцарських кантонах Гларус і Аппенцелль-Внутрішній і в деяких міських громадах й досі працює «прямий безпосередній народний збір». Тому діалог та дискусія є «душею» будь-якої справжньої демократії [4].

Слід зазначити, що зараз у світі більшість всіх країн залишаються формально демократичними, i це в умовах загальної кризи самої ідеї демократичного правління. Але, спостерігаються зараз й процеси автократизації, які мають нові риси і особливості. Наприклад, якщо раніше так процеси відбувалися в країнах, де базис для відмови від демократії вже мав місце, або ж в країнах зі слабкими демократичними традиціями, то зараз ці процеси охоплюють навіть старі стабільні демократії. Це пояснюється тим, що автократія (на думку суспільства) дозволяє швидше вирішувати нагальні 
питання, на які в умовах демократій витрачається дуже багато часу. I якщо раніше диктатура приходила до влади в результаті іноземних вторгнень або після військових переворотів, то сьогодні цей процес вже має більш витончений характер, замаскований демократичними змінами в законодавстві. Типовий приклад такого розвитку в бік автократії (тоталітаризму) спостерігаємо в Росії, де на тлі коронавірусної пандемії був швидко організований урядовий плебісцит, який дозволив В.Путіну залишитися при владі до 2036 року. Це, безумовно, дуже сумнівні практики, які являють собою повну протилежність справжньому демократичному суспільству.

Відповідно до даних правозахисної організації Freedom House за 2020 рік «Держави перехідного періоду»: «....демократичний рейтинг України дещо зріс завдяки належно проведеним виборам 2019 року і мирному переходові влади, але перед державою стоять нелегкі виклики в галузі дотримання демократії....Рейтинг рівня демократії в Україні склав 3,39- це деяке поліпшення 3 попереднього показника 3,36. Таким чином, Україна залишилася в розділі «перехідних чи гібридних режимів». А індекс демократії в ній становить $40 \%$. Ця оцінка стосується вільної території країни. Становище на окупованих територіях, у Криму й на частині Донбасу, на неї не вплинуло» [3]. В даній доповіді визначається, що «..зростання рівня демократії відбулося в одній із семи досліджуваних галузей - демократичному управлінні державою. Шість інших залишилися незмінними (виборчий процес, громадянське суспільство, незалежні засоби інформації, демократичне управління на місцевому рівні, структура й незалежність системи правосуддя, а також корупція)» [3].

Але, слід зазначити, що є деякі тонкощі таких індексів та рейтингів. Так, діяльність Freedom House дійсно $\epsilon$ необхідною та корисною, і це $\epsilon$ важливим для розуміння того, як відбувається внутрішня динаміка розвитку України, особливо в порівнянні з іншими країнами. I це безумовно впливає на міжнародний імідж нашої країни. Однак, як правильно зазначає С.Шаповалов, «... важливо розуміти тонкощі інтерпретації подібних оцінок.... слід з обережністю сприймати висновки Freedom House щодо України...головною проблемою $є$ непрозорість оцінювання дослідження Nations in Transit» [6].

Висновки. Можна зробити висновок, що актуальним завданням зараз $є$ використання можливостей, які виникають в перехідних процесах в мінливих суспільствах. Це необхідно для одночасного поглиблення задач, що стоять перед демократією та розвитком. Необхідним $\epsilon$ забезпечення того, щоб національні плани розвитку та економічні реформи набули всеохоплюючого та колективного характеру, щоб інститути держави ставали все більш підзвітними і щоб структура виборчих і конституційних процесів забезпечувала максимальну участь громадян, особливо меншин, жінок і вразливих груп населення. Підзвітність та прозорість, засновані на принципі стримувань та противаг є головними складовими, які в найближчі роки залишаються однією з найважливіших задач для країн, де формується демократія і це має вирішальне значення для перспектив їх розвитку.

Перспективним напрямом подальшого дослідження. Необхідно переосмислити традиційний підхід до зміцнення демократії, а також загальноприйняті порядки надання допомоги в цілях розвитку. Також слід більш глибоко опрацювати концепцію демократичного розвитку. Особливо звернути увагу на визначення мети такого розвитку: усування відособленості в справі зміцнення демократії і практиці здійснення партнерства заради розвитку, особливо в плані узгодженості їх реалізації, визначення рівня впливу прав та участі громадян на ймовірність стійкого прогресу розвитку суспільства та держави.

\section{Бібліографічний список:}

1. Altman D. Citizenship and Contemporary Direct Democracy Pontificia Universidad Catolica de Chile. Cambridge University Press. 2018, 135.

2. https://www.v-dem.net/

3. Драчук С. Демократичний рейтинг України дещо зріс, але перед нею стоять виклики в дотриманні демократії. Freedom House. 2020. https://www.radiosvoboda.org/

4. Кауфманн Б. Десять признаков демократического общества с точки зрения Швейцарии. 2019. https://www.swissinfo.ch/

5. Томмазоли М. Демократия и развитие: роль ООН. ИИДЕА, 2013, 65 с.

6. Шаповалов С. Україна на терезах демократії: Індекс Freedom House. Фонд «Демократичні ініціативи» імені Ілька Кучеріва в рамках Програми сприяння громадській активності «Долучайся!», 2020. https://dif.org.ua/

\section{References:}

1. Altman D. Citizenship and Contemporary Direct Democracy Pontificia Universidad Catolica de Chile. Cambridge University Press. 2018, 135.

2. https://www.v-dem.net/ 
3. Drachuk S. Demokratychnyi reitynh Ukrainy deshcho zris, ale pered neiu stoiat vyklyky v dotrymanni demokratii. Freedom House. 2020. https://www.radiosvoboda.org/

4. Kaufmann B. Desyat pryznakov demokratycheskogo obshhestva s tochky zrenya Shvejczaryy. 2019. https://www.swissinfo.ch/

5. Tommazoly M. Demokratya y razvytye: rol OON. YYDEA, 2013, 65 s.

6. Shapovalov S. Ukraina na terezakh demokratii: Indeks Freedom House. Fond «Demokratychni initsiatyvy» imeni Ilka Kucheriva v ramkakh Prohramy spryiannia hromadskii aktyvnosti «Doluchaisia!», 2020. https://dif.org.ua/

\section{Mishyn S. I. Democratic Retrofits: Criteria and Factors}

The article is aimed at studying democratic changes in terms of characterization of criteria and factors of these transformations. The modern political process can have different trajectories and fluctuations. They determine the directions of political transformations. These can be a wide range of political regimes: from democracies to new forms of autocracy and dictatorships. And it is important here to determine what are the objective conditions that promote or hinder the formation of new democratic institutions. Therefore, this article draws attention to the identification of key factors influencing the trajectories and results of regime change. Directly, attention is paid to the analysis of factors and processes that are important to explain the nature and results of regime transformations.

It is determined that the urgent task now is to use the opportunities that arise in transition processes in changing societies. This is necessary to simultaneously deepen the challenges facing democracy and development. There is a need to ensure that national development plans and economic reforms are comprehensive and collective, that state institutions become more accountable and that the structure of electoral and constitutional processes ensures the maximum participation of citizens, especially minorities, women and vulnerable groups. Accountability and transparency, based on the principle of checks and balances, are the main components that in the coming years will remain one of the most important tasks for countries where democracy is being formed and this is crucial for their development prospects.

It is justified that the traditional approach to strengthening democracy should be reconsidered, as well as the generally accepted procedures for providing development assistance. The concept of democratic development should also be further developed. Particular attention should be paid to defining the purpose of such development: eliminating isolation in strengthening democracy and the practice of partnership for development, especially in terms of coherence of their implementation, determining the level of influence of rights and participation of citizens on the likelihood of sustainable progress.

Keywords: democracy, transformations, changes, democratic regime, political transformations 